\title{
Post-injection embolia cutis medicamentosa - Nicolau Syndrome: case report and literature review
}

\author{
Embolia cutis medicamentosa pós-injeção - Síndrome de Nicolau: \\ relato de caso e revisão de literatura \\ Carlos Alberto Araujo Chagas', Tulio Fabiano de Oliveira Leite ${ }^{2}$, Lucas Alves Sarmento Pires ${ }^{1}$
}

\begin{abstract}
We report on the case of a 40-year-old male who was admitted to the clinic with a large ulcer on his left buttock, 3 days after an intramuscular benzathine penicillin injection. The patient was diagnosed with Nicolau syndrome, a rare vascular complication in which a lesion develops after intramuscular injection. Symptoms are intense pain at the injection site, erythema, and livedoid dermatitis, which leads to necrosis of skin, subcutaneous tissue and muscle tissue. It was described by Nicolau after intramuscular injections of bismuth salt for syphillis therapy. Nicolau syndrome is rare, but its symptoms are devastating and healthcare professionals must be aware of this clinical entity, since intramuscular injections are common procedures for administration of drugs.
\end{abstract}

Keywords: Nicolau syndrome; injections, intramuscular; ulcer.

\begin{abstract}
Resumo
Relatamos o caso de um homem de 40 anos apresentando uma grande úlcera na nádega esquerda 3 dias após receber injeção intramuscular de penicilina benzatina. O paciente foi diagnosticado com síndrome de Nicolau, uma rara complicação vascular com lesão após injeções intramusculares. Os sintomas incluem dor intensa no local da injeção, eritema e dermatite livedoide, o que leva a necrose da pele, do tecido subcutâneo e do tecido muscular. Foi descrita por Nicolau após injeções intramusculares de sal de bismuto para o tratamento de síflis. A síndrome de Nicolau é incomum, mas seus sintomas são devastadores. Portanto, os profissionais de saúde precisam conhecer essa entidade clínica, uma vez que as injeções intramusculares são procedimentos comuns para a administração de drogas.
\end{abstract}

Palavras-chave: síndrome de Nicolau; injeções intramusculares; úlcera.

${ }^{1}$ Universidade Federal Fluminense - UFF, Niterói, RJ, Brazil.

${ }^{2}$ Universidade Estadual Paulista - UNESP, Cirurgia Vascular, São Paulo, SP, Brazil.

Financial support: None.

Conflicts of interest: No conflicts of interest declared concerning the publication of this article.

Submitted: October 23, 2015. Accepted: November 23, 2015. 


\section{INTRODUCTION}

Intramuscular injections for administering drugs are common procedures because they are effective and offer rapid response times. ${ }^{1}$ Nicolau syndrome or embolia cutis medicamentosa is a rare complication that can occur after intramuscular, intra-articular or subcutaneous injections. ${ }^{2,3}$ The incidence of complications of intramuscular injections varies between $0.4 \%$ and $19.3 \%$ and the most common forms are sciatic nerve injury, hematoma, and bleeding. ${ }^{1}$ Nicolau syndrome presents with pain at the site of injection immediately after drug administration, followed by hyperemia, skin discoloration, abscess formation, and ischemic necrosis and severe cases can even lead to death. ${ }^{1,4,5}$ The syndrome occurs when a drug is injected inside the arterial wall or lumen, which leads to thrombosis and subsequent tissue necrosis. ${ }^{6}$ This clinical entity is associated with drugs such as benzathine penicillin, non-steroidal anti-inflammatories, local anesthetics, corticosteroids and vaccines. ${ }^{5-8}$ We report a case of Nicolau syndrome in a 40 -year-old male.

\section{CASE REPORT}

A 40-year-old male reported intense pain in his left buttock after intramuscular administration of benzathine penicillin. Three days later an ulcer developed in his left buttock. Physical examination revealed a large ulcer with necrotic borders and exudate within the wound and the ulcer had also exposed the gluteus maximus muscle (Figure 1). The patient was diagnosed with Nicolau syndrome and treated with debridement, sterile dressings, non-steroidal anti-inflammatories, analgesics, and low-molecular-weight heparin. A slight improvement could be seen 5 days after the initial treatment, (Figure 2).

\section{DISCUSSION}

Nicolau syndrome (NS) is also known as embolia cutis medicamentosa or livedoid dermatitis. Between 1893 and 1920, countless cases were reported by Fournier, Welander, Nicolsky, Juliusberg, and Freudenthal. In 1925, Nicolau observed complications of intramuscular injections with mercurial or bismuth salt for syphilis treatment, describing the phenomenon more accurately. ${ }^{5,7-9}$

This is a rare reaction involving skin, subcutaneous tissue, and muscle tissue and can be seen as a complication of intramuscular, intra-articular or subcutaneous injections, the last of which is the rarest cause. The incidence of reactions to intramuscular injection varies from $0.4 \%$ to $19.3 \%$ and the most common types of complications include bleeding at the injection site, hematoma, and sciatic nerve injury. Nicolau syndrome has lower incidence than all of these complications..$^{1-3,10,11}$ Children less than 12 years old are more susceptible to developing NS after administration of antibiotics. ${ }^{12,13}$ Nicolau syndrome occurs with greater frequency in obese patients and women, since they have larger deposits of fat tissues in the gluteal region, which prevents needles from reaching muscle tissues. ${ }^{1}$

The phenomena is mostly described with relation to antibiotics (benzathine penicillin) and non-steroidal anti-inflammatory drugs (NSAIDs), but cases of NS have also been described associated with vitamin B complex, vitamin $\mathrm{K}$, etanercept, local anesthetics (lidocaine),

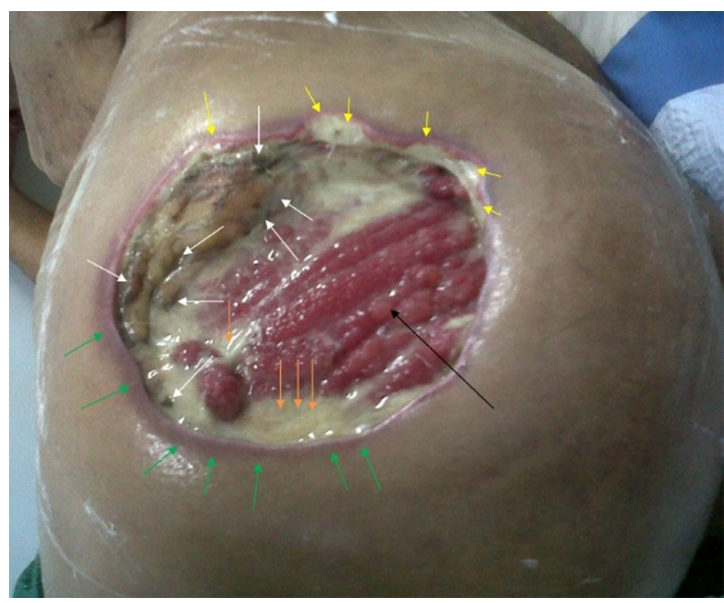

Figure 1. Gluteus maximus muscle (black arrow), ischemic process (yellow arrow), necrotic borders (white arrow), and exudate (orange arrow). In some areas of the border there is also intense inflammation and hyperemia (green arrows).

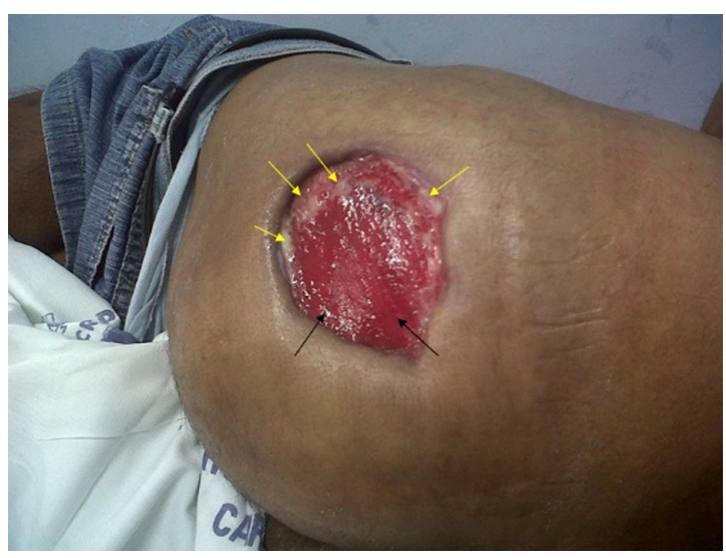

Figure 2. There is still gluteus maximus muscle exposure, but there is no longer any exudate or necrotic material and there has been a considerable reduction in the inflammatory process. In certain regions of the ulcer, fibrin production can be seen (yellow arrow). 
glucocorticoids (prednisolone), interferon-alpha, phenylbutazone, phenobarbital, glatiramer acetate, antihistamine drugs, bortezomib, and DTP-polio-Hib vaccine. .,6-8, $12-16^{-16}$

The physiopathology of NS is not well-established, but the following hypotheses have been suggested: (1) inflammation caused by vascular or perivascular injection, which induces arterial wall destruction and subsequent tissue necrosis, (2) embolism caused by intra-arterial injection, causing occlusion of small vessels, (3) periarterial injection associated with arterial wall perforation, leading to thrombosis and necrosis, (4) sympathetic stimuli caused by intra-arterial injection, resulting in vasospasm, (5) direct trauma provoked by the needle. However, immunologic response mechanisms have been ruled out because recurrence of NS with the same pharmacological agent has not been described. $3,6,8,11,12,17,18$ Nicolau observed the presence of residues of bismuth salts in histological examination of the lumen of small vessels, which may have caused an embolic process. Furthermore, in 1967, occlusive substances were found in arteries of the forearm of a patient who suffered from NS after penicillin injection and this not only confirms the embolic pathophysiological mechanism, but also confirms that NS can cause lesions outside of the original area. Moreover, animal models have confirmed vasospasm reaction caused by injections, leading to tunica intima damage. . $^{7,9,18,19-21}$

The pharmacological properties of injected drugs can also contribute to onset of NS. For example, the NSAIDs are cyclooxygenase inhibitors, and therefore cause vascular spasm and subsequent restriction of blood circulation, since the enzyme inhibits prostaglandin synthesis. ${ }^{1,7}$

Clinically, NS presents in the form of a burning sensation and extreme pain immediately after the injection, followed by the appearance of bluish or purple web-like lesions (described as a pathognomonic sign) and skin discoloration. After a few days this reaction causes hemorrhage and ulceration of skin, subcutaneous tissue and muscle tissue. .,4,6,10,15 $^{2}$ In severe cases, the syndrome can progress to rectal hemorrhage, compartment syndrome, acute renal failure, rhabdomyolysis, permanent ischemia of the ipsilateral limb, and sepsis. If embolization is involved, this can cause pulmonary embolism and distal lesions of the ipsilateral limb via the circulation. Nicolau syndrome can be fatal in children., 3,9,13,22 Furthermore, the syndrome can cause neurological complications, such as paraplegia, hypoesthesia, and stereognosis. In 2010, a case of NS was described that progressed to irreversible lesion of a lower limb and vesical sphincter dysfunction, caused by a reduction of blood flow in the inferior gluteal artery, which led to compromised irrigation of the sciatic and pudendal nerves. ${ }^{13,20}$ In 2014, the first case of NS associated with ipsilateral testicular torsion was described. ${ }^{12}$

Diagnosis of NS is based on clinical findings, since laboratory exams are non-specific. Skin biopsy usually reveals thrombosis of small and medium caliber arteries and non-specific necrosis and inflammatory processes., ${ }^{2,8,11,13,21}$ Doppler ultrasound can show possible vessel occlusion and magnetic resonance imaging can identify the extent of the lesion. ${ }^{22}$ Differential diagnosis should include necrotizing fasciitis, calciphylaxis, arteriosclerosis, fat embolism, vasculitis, and cardiac myxoma - the last of which is often associated with skin lesions in acral regions and is also related to cardiopulmonary symptoms. Nicolau syndrome can also be similar to an abscess. , $^{3,14,17,23,24}$

There is no standard treatment established for NS, since it has a low incidence. In most cases, methods such as surgical debridement and local repair through grafts or myocutaneous flap combined with anticoagulants, pentoxifylline, hyperbaric chamber, steroids, intravenous alprostadil, corticosteroids and analgesics are employed until the lesion is completely healed. ${ }^{3,5,10,11}$ The use of a hyperbaric chamber (HC) is justified by the fact that it provides increased oxygen supply, which reduces edema and stimulates neoangiogenesis and because an $\mathrm{HC}$ also stimulates fibroblast production. Although not universally accepted, some authors recommend using an $\mathrm{HC}$ immediately after NS is diagnosed. Pentoxifylline can also be used, since it is a phosphodiesterase inhibitor that improves blood cell deformability and improves blood flow conditions by reducing vasospasm. ${ }^{3,13,18,24}$ Ice compresses should be avoided because they increase vasoconstriction, thereby worsening the condition. ${ }^{25}$

Prevention of NS can be achieved by adopting the following precautionary measures: injecting the drug in the upper and outer quadrant of the gluteal region, because this area has fewer large caliber vessels; performing syringe aspiration before injecting the drug to test for the presence of blood; utilizing the $\mathrm{Z}$ technique for intramuscular injections; respecting the $5 \mathrm{ml} \mathrm{limit}$; alternating the injection site in cases of multiple doses or long treatments; and using a needle that is longer than $3.8 \mathrm{~cm}$ in obese patients. ${ }^{1,4,5,23}$

Although NS is a rare reaction, the symptoms are extremely dangerous and so healthcare professionals must be aware of this clinical entity and know how to avoid it by taking preventive measures, since intramuscular, intra-articular and subcutaneous injections are all common procedures. 


\section{REFERENCES}

1. Dadaci M, Altuntas Z, Ince B, Bilgen F, Tufekci O, Poyraz N. Nicolau Syndrome after intramuscular injection of non-steroidal antiinflammatory drugs (NSAID). Bosn J Basic Med Sci. 2015;15(1):57-60. http://dx.doi.org/10.17305/bjbms.2015.1.190. PMid:25725145.

2. Pérez AP, Blanco VP, Fernández RS. Síndrome de Nicolau tras la administración de acetato de glatirámero. Neurologia. 2013;28(7):4489. http://dx.doi.org/10.1016/j.nrl.2012.04.010. PMid:22698594.

3. Lopes L, Filipe P, Alves A, Guerreiro F, Pires S. Nicolau syndrome after benzathine penicillin treated with hyperbaric oxygen therapy. Int J Dermatol. 2015;54(4):e103-6. http://dx.doi.org/10.1111/ ijd.12751. PMid:25557534.

4. Senel E. Nicolau syndrome as an avoidable complication.J Family Community Med. 2012;19(1):52-3. http://dx.doi.org/10.4103/22308229.94017. PMid:22518360.

5. Kılıç I, Kaya F, Özdemir AT, Demirel T, Çelik I. Nicolau syndrome due to diclofenac sodium (Voltaren ${ }^{\oplus}$ ) injection a case report. J Med Case Reports. 2014;8:404. http://dx.doi.org/10.1186/17521947-8-404. PMid:25471251.

6. Bégin $P$, Anne DR. Nicolau syndrome may be caused by intravascular vaccine injection. Vaccine. 2012;30(11):2035-6. http://dx.doi. org/10.1016/j.vaccine.2011.10.107. PMid:22198515.

7. Kim SK, Kim TH, Lee KC. Nicolau syndrome after intramuscular injection: 3 cases. Arch Plast Surg. 2012;39(3):249-52. http://dx.doi. org/10.5999/aps.2012.39.3.249. PMid:22783535.

8. Almudimeegh A, Pelletier FL, Dupin N. Nicolau syndrome secondary to subcutaneous Bortezomib injection. J Eur Acad Dermatol Venereol. 2014;30(2):348-50. PMid:25264810.

9. Duque $\mathrm{FL}, \mathrm{Chagas} \mathrm{CA}$. Acidente por injeção medicamentosa no músculo deltoide: lesões locais e à distância, revisão de 32 casos. J Vasc Bras. 2009;8(3):238-46. http://dx.doi.org/10.1590/ S1677-54492009000300009.

10. Korkomaz J, Maatouk I, Moutran R, Hélou J. Nicolau livedoid dermatitis occurring after sclerotherapy. Vasc Med. 2014;19(5):4156. http://dx.doi.org/10.1177/1358863X14537884. PMid:25305275.

11. Noaparast M, Mirsharifi R, Elyasinia F, Parsaei R, Kondori H, Farifteh A. Nicolau Syndrome after Intramuscular Benzathine Penicillin Injection. Iran J Med Sci. 2014;39(6):577-9. PMid:25429182.

12. Bellot B, Bonnet $C$, Retornaz K, et al. Complication d'une injection intramusculaire ou syndrome de Nicolau. Arch Pediatr. 2014;21(4):377-80. http://dx.doi.org/10.1016/j.arcped.2014.01.016. PMid:24630542.

13. Ergul Y, Soydemir D, Tastan Y, Omeroglu RE. Does early hyperbaric oxygen therapy prevent extremity necrosis in Nicolau syndrome? Pediatr Int. 2012;54(3):e15-8. http://dx.doi.org/10.1111/j.1442200X.2011.03475.x. PMid:22631583.

14. Perli D, Martone C, Rapose A. Naltrexone-induced Nicolau syndrome masquerading as cutaneous abscess. BMJ Case Rep. 2012;2012:14. http://dx.doi.org/10.1136/bcr-2012-007785. PMid:23242099.

15. Masthan Saheb D, Madhav S, Reddy KC, Lakshmi S, Prabha R, Anandam K. Nicolau syndrome. Indian J Dermatol Venereol Leprol. 2002;68(1):45-6. PMid:17656870.

16. Deissert S. Embolia cuits medicamentosa (Nicolau syndrome) nach intra aricurarer injektion. Hautarzt. 1999:50214-6.

17. McKinney C, Sharma N, Jerath RS. Livedoid dermatitis (Nicolau Syndrome) following intra-articular glucocorticoid injection. J Clin Rheumatol. 2014;20(6):339-40. PMid:25160024.
18. Perissé R, Fernandes AD, Monteiro A, Cortes JC, Meirelles ML, Azambuja M. Acidentes vasculares por injeção. J Bras Med. 1967:13213-8.

19. Andrade P, Pereira N, Brites MM, Gonçalo M, Figueiredo A. Nicolau livedoid dermatitis following intramuscular benzathine penicillin injection. Dermatol Online J. 2010;16(11):11. PMid:21199637.

20. Kim DH, Ahn HH, Kye YC, Choi JE. Nicolau syndrome involving whole ipsilateral limb induced by intramuscular administration of gentamycin. Indian J Dermatol Venereol Leprol. 2014;80(1):96. http://dx.doi.org/10.4103/0378-6323.125516. PMid:24448148.

21. Zaragoza J, Delaplace $M$, Benamara $M$, Estève E. A rare side effect of mesotherapy: Nicolau syndrome. Ann Dermatol Venereol. 2013;140(11):713-7. http://dx.doi.org/10.1016/j.annder.2013.07.009. PMid:24206808.

22. Nirmal B, Segu SS, Sacchidanand SA, Deshpande P. Nicolau syndrome following sclerotherapy for pyogenic granuloma. Indian J Dermatol Venereol Leprol. 2014;80(5):484. http://dx.doi. org/10.4103/0378-6323.140356. PMid:25201872.

23. Nayci S, Gurel MS. Nicolau syndrome following intramuscular diclofenac injection. Indian Dermatol Online J. 2013;4(2):152-3. http://dx.doi.org/10.4103/2229-5178.110642. PMid:23741679.

24. Silva AM, Loureiro TF, Ton A, Agrizzi BL. Síndrome de Nicolau de desenvolvimento tardio - relato de caso. An Bras Dermatol. 2011;86(1):157-9. http://dx.doi.org/10.1590/S0365-05962011000100026. PMid:21437542.

25. Senel E, Ada S, Güleç AT, Caglar B. Nicolau syndrome aggravated by cold application after i.m. diclofenac.J Dermatol. 2008;35(1):1820. http://dx.doi.org/10.1111/j.1346-8138.2007.00402.x-i1. PMid: 18181770

Correspondence Carlos Alberto Araujo Chagas Rua Professor Ernani Mello, 101 - São Domingos CEP 24210-150 - Niterói (RJ), Brazil Tel.: +55 (21) 2629-2335 / +55 (21) 98821-0066 E-mail:chagas@vm.uff.br

Author information

CAAC - MSc in Morphology from Universidade Federal do Rio de Janeiro (UFRJ); Angiologist in Rio de Janeiro; Chief of Angiology Service at Hospital Geral da Santa Casa da Misericórdia do Rio de Janeiro (HGSCMRI); Professor at Universidade Federal Fluminense

(UFF)

TFOL - Resident physician (R4) of Vascular Surgery at Universidade Estadual Paulista (UNESP) LASP - Nursing student at Universidade Federal Fluminense (UFF)

Author contributions Conception and design: CAAC, TFOL, LASP Analysis and interpretation: CAAC, TFOL, LASP Data collection: CAAC, TFOL, LASP Writing the article: CAAC, TFOL, LASP Critical revision of the article: CAAC, TFOL Final approval of the article*: CAAC, TFOL, LASP Statistical analysis: CAAC, TFOL, LASP Overall responsibility: CAAC

*All authors have read and approved of the final version of the article submitted to J Vasc Bras. 